\title{
MANAJEMEN KEPEMIMPINAN ISLAMI DALAM MENINGKATKAN KINERJA KARYAWAN DI UD IQBAL JAYA BONDOWOSO
}

\author{
Rahmat dan Ahmad \\ rahmatulla.albaweany@gmail.com \\ ahjelly@gmail.com \\ STAI Syaichona Moh.Cholil Bangkalan
}

\begin{abstract}
ABSTRAK
Leadership management is the ability of a leader to manage the organization he leads. This is done so that the organization he leads runs properly and correctly. Every business activity carried out by the company or the like must have a leader who applies leadership management

The leadership management implemented at UD Iqbal Jaya is leadership management that leads to siddik, Amanah, Tabligh and Fatonah characteristics. These four characteristics are the main factors in influencing and increasing employee loyalty.
\end{abstract}

Keywords: Leadership Management, employee performance

\section{PENDAHULUAN}

Dalamsebuahorganisasikepemimpinanmerupakanmesinutamanya.Olehkarenaitu majuataumundurnyasuatuorganisasitergantungdengankuatatautidaknyapemimpinmengat ur, mengeloladanmemberdayakanparaanggotnya.Kepemimpinan merupakan proses mempengaruhi orang lain agar termotivasi dan tergerak dalam mencapai tujuan organisasi. Kepemimpinan merupakan kuasa seseorang dalam mempengaruhi, mendorong, membimbing, mengarahkan dan menggerakkan orang lain agar mau bekerjasama dengan penuh semangat dan kepercayaan dalam mencapai tujuan bersama (Muhammad Syafi'i Antonio, 2007).

Sudah kita ketahui bahwa pemimpin atau leader adalah orang yang mempunyai bawahan atau orang yang mengendalikan jalannya organisasi(Onong Uchjana Efendi, 2009).Sebagai agama yang sesuai dengan fitrah manusia, Islam memberikan prinsip dasardan tata nilai dalam mengelola organisasi atau perusahaan. Al-qur'an dan Assunnah dalampermasalahan ini telah mengisyaratkan beberapa prinsip pokok dan tata nilai yang berkaitan dengankepemimpinan, kehidupan bermasyarakat dan berorganisasi 
serta perusahaan termasuk di dalamnya adamanajamen usaha yang nota-benenya merupakan kontrak sosial. Agar dapat melaksanakan tugasnya dengan sempurna maka ia harus memiliki pedoman atau konsep-konsep yang jelas dalam menjalankan kepemimpinannya di masyarakat, kantor ataupun instansi pemerintah.

Menurut Nawawi dari segiajaran Islam, kepemimpinan merupakan kegiatan menuntun, membimbing,memandu dan menunjukkan jalan yang diridhoi Allah Swt. Jadi orientasiutama dalam kepemimpinan Islam adalah keridhaan Allah(Hadari Nawawi, 1993).Dengan tugas dan tanggung jawab tersebut, menunjukkan bahwa manusia merupakan pemimpin, melaksanakan tugas kepemimpinan di bumi sebagai amanah dari sang pencipta. Dalam kehidupan sosial, suatu masyarakat tidak dapat dipisahkan dari sebuah kepemimpinan. Kepemimpinan dibutuhkan setiap hari, baik dalam lingkungan keluarga atau rumah tangga, dalam pekerjaan di kantor atau di perusahaan, dan dalam aktifitas-aktifitas kehidupan sosial lainnya dalam masyarakat.

Kepemimpinan telah terbukti sebagai aset berharga bagi suatu perusahaan.Bahkan diantara komponen-komponen lain organisasi seperti struktur, budaya, praktik manajerial, misi, visi, tujuan, strategi, kebijakan, prosedur serta iklim kerja, kepemimpinan merupakan salah satu komponen terpenting atau inti.Bass menyatakan bahwa kualitas dari pemimpin sering dianggap sebagai faktor terpenting yang menentukan keberhasilan atau kegagalan organisasi.Nielsen dan Daniels juga menyatakan bahwa pemimpin mempunyai pengaruh besar terhadap keberhasilan organisasi.Pentingnya peran kepemimpinan dalam sebuah perusahaan menjadi konsep yang menarik perhatian para peneliti untuk melakukan penelitian dibidang perilaku keorganisasian ini.

Manajemen adalah skill atau kemampuan dalam mempengaruhi orang lain agar mau melakukan sesuatu untuk kita. Manajemen memiliki kaitan yang sangat erat dengan leader atau pemimpin. Sebab pemimpin yang sebenanrnya adalah seseorang yang mempunyai kemampuan untuk menjadikan orang lain lebih dihargai, sehinnga orang lain akan melakukan segala keinginan sang leader.

Manajemen menurut bahasa arab disebut Idarah yang sepadan dengan kata tadbir yang berarti pengaturan, pengurusan, perencanaan dan persiapan. Secara istilah, sebagian pengamat mengartikannya mengatakan bahwa manajemen syari'ah adalah suatu aktivitas khusus menyangkut kepemimpinan, pengarahan, pengembangan 
personal, perencanaan, dan pengawasan terhadap pekerjaan-pekerjaan yang berkenaan dengan unsur-unsur pokok dalam suatu proyek/usaha yang sesuai dengan syari'ah(Muhammad, 2012).

Dalam manajemen yang sangat berperan penting adalah seorang manajer. Manajer adalah seorang anggota yang memiliki otoritas resmi untuk memberitahu orang-orang lain mengenai apa yang harus di kerjakan dan bagaimana cara mengerjakan dan apa hasil dari pekerjaan tersebut.Dengan demikian, manajemen merupakan suatu kebutuhan yang tak terelakkan sebagai alat untuk memudahkan pencapaian tujuan manusia dalam organisasi, sebagai suatu sistem yang bersifat sosio-ekonomi-teknis dan aplikasinya bersifat bebas nilai serta hanya berorientasi pada pencapaian manfaat bendawi semata.

Manajemen kepemimpinan adalah kemampuan seorang pemimpin dalam mengelola subuah organisasi yang dipimpinnya. Hal ini dilakukan agar organisasi yang dipimpinnya berjalan sesuai dengan baik dan benar. Setiap kegiatan usaha yang dilakukan oleh perusahaan ataupun sejanisnya sudah mesti memeliki pemimpin yang menerapkan manajemen kepemimpinannya. Termasuk usaha yang menerapkan manajemen kepemimpinan adalah UD Iqbal Jaya Bondowoso. UD Iqbal Jaya merupakan sejenis pabrik atau PT yang bergerak di bidang produksi tahu yang telah didirikan oleh bapak Hamadin sejak tahun 1999 di desa kalianyar Kecamatan Tamanan Kabupaten Bondowoso.

Dalam kegiatan usahanya yang sudah berjalan kurang lebih sekitar 20 tahun UD iqbal jaya tetap exis didunia bisnisnya. Hal ini dikerenakan kekuatan kepemimpinan yang dimiliki oleh bapak Hamadin selaku pendiri dan pimpinan UD. Dengan kepiawan pak Hamadin selaku pimpinan UD, maka para karyawan yang bekerjapun menjadi semangat tanpa merasakan beban apapun saat bekerja. Bagi pak Hamadin para pekerja bukanlah buruh yang harus di paksa, bagi pak Hamadin para pekerja adalah keluarga yang harus selalu di ayomi dan dikasihi. Adalah akibat dari sifat dan manajemen yang digunakan pak Hamadin hingga saat ini UD Iqbal Jaya tetap exis.

Dari paparan singkat tersebut, peneliti ingin memaparkan tentang manajemen kepemimpinan Islami di UD Iqbal Jaya dalam meningkatkan kinerja karyawan. Bagi peneliti hal ini menjadi penting untuk mengetahui penerapan manajemen kepemimpinan Islam dalam sebuah perusahaan. Namun, secara akademik penelitian ini akan 
bermamfaat bagi peneliti berikutnya dalam mengkaji penerapan manajemen kepemimpinan di perusahaan.

\section{KAJIAN TEORI}

\section{Manajemen}

Para ahli banyak yang berbeda pendapat dalam menyikapi manajemen, sekalipun berbeda pendapat, akan tetapi jika dilihat dari tujuan manajemen maka akan terlihat arah yang sama. Adapun beberapa fungsi-fungsi manajemen sebagaimana pendapat berikut:

a. Henry Fayol Berpendapat bahwa fungsi mnajemen adalah: Planning, organizing, commanding, Leanding, Controling yaitu perencanaa, pengorganisasian, pemberian perintah, pengordinasian, dan pengendalian.

b. Louis Allen Berkomentar bahwa fungsi manajemen adalah Planning, Organizing, Leading, Controlling ( Perencanaan, Pengorganisasian, Pengarahan, Pengawasan) (Hendyat Soetopo, 1992).

c. Stephen P. Robbin Berpendapat sama dengan Allen yaitu : Planning, Organizing,

Leading, Controlling ( Perencanaan, Pengorganisasian, Pengarahan, Pengawasan).

Dari tiga pendapat tersebut diatas, kenyataan para ahli lebih cenderung kepada pendapat Allen sebagai fungsi pokok manejemen, yaitu Planning, Organizing, Leading, dan Controlling (Perencanaan, Pengorganisasian, Pengarahan, dan Pengawasan). Jadi pada dasarnya manajemen adalah upaya mengatur segala sesuatu (sumber daya) untuk mencapai tujuan organisasi. Dalam kegiatan mengatur ini kemudian timbul beberapa masalah. Siapa yang mengatur, mengapa harus diatur, dan apa tujuan dari pengaturan tersebut. Dari pernyataan tersebut maka diperlukan kegiatan mempelajari, mendalami dan mempraktikkan konsep manajemen secara baik sehingga tujuan organisasi dapat dicapai dengan baik.

Secara bahasa manajemen berasal dari kata to manage yang berarti mengatur. Akantetapi jika dilihat dari literatur yang ada, maka pengertian manajemen selalu mengarah kepada tiga pengertian manajemen sebagai suatu proses, manajemen sebagai suatu kolektifitas manusia, manajemen sebagai ilmu (science) dan sebagai seni (art) (Anang Firmansyah, 2019).

Ilmu manajemen merupakan suatu ilmu yang mempelajari cara mencapai suatu tujuan dengan efektif dan efisien dengan menggunakan bantuan orang lain. 
Menggunakan bantuan atau melalui orang lain dalam hal ini mencakup arti yang sangat luas, yaitu dapat berupa bantuan orang lain dalam wujud pemikiran, tenaga serta dapat pula intuisinya. Sementara itu pengertian efektifitas ataupun efisiensi dalam rangka mencapai tujuan organisasi dengan melalui orang lain pada dasarnya dapat dipengaruhi dua faktor, yaitu ilmu manajemen (science) dan seni (art) (John Supriyanto, 2014).

Menurut Manulang mendefinisikan manajemen sebagai suatu seni dan ilmu perencanaan, pengorganisasian, pengarahan, penyusunan dan pengawasan daripada sumber daya manusia untuk mencapai suatu tujuan yang telah ditetapkan oleh penerbit. G.R Terry memberikan mungemukakan bahwa manajemen merupakan proses yang khas terdiri dari perencanaan, pengarahan, dan pengendalian yang dilakukan untuk menentukan serta mencapai tujuan-tujuan yang diinginkan melalui pemanfaatan sember daya manusia dan sumber daya lainnya. Sedangkan menurut Kamus Besar Bahasa Indonesia, manajemen diartikan sebagai proses penggunaan sumber daya secara efektif untuk mencapai sasaran.

Dalam istilah manajemen terdapat tiga pandangan yang berbeda yaitu:

1. Mengartikan administrasi lebih luas daripada manajemen (manajemen merupakan inti administrasi).

2. Melihat manajemen lebih luas dari administrasi.

3. Pandangan yang beranggapan bahwa manajemen identik dengan administrasi (Muhammad Nizar, 2018).

Berdasarkan pengertian-pengertian yang telah dijelaskan diatas, maka dapat diambil kesimpulan bahwa manajemen merupakan suatu rangkaian kegiatan mulai dari perencanaan, pengorganisasian, pengarahan, pengendalian serta pengawasan dengan memanfaatkan sumber daya manusia serta sumber-sumber daya lainnya untuk mencapai suatu tujuan organisasi yang telah ditentukan.

Fungsi manajemen adalah elemen pokok yang ada dan selalu melekat di dalam proses manajemen yang akan dijadikan acuan oleh manajer dalam melaksanakan kegiatan untuk mencapai tujuan. Fungsi manajemen pertama kali diperkenalkan oleh seorang industrialis Perancis bernama Henry Fayol pada awal abad ke-20. Ada 4 fungsi dalam manajemen yaitu (Hendri Safri, 2017): 
1. Perencanaan (Planning) adalah tentang rencana-rencana dari yang sangat sederhana sampai dengan yang sangat rumit. Misalnya merumuskan bahwa perencanaan adalah penentuan serangkaian tindakan untuk mencapai suatu hasil yang diinginkan.

2. Pengorganisasian (Organizing) adalah dua orang atau lebih yang bekerja sama dalam acara yang terstruktur untuk mencapai sasaran spesifik atau sejumlah sasaran.

3. Leading, meliputi lima kegiatan yaitu:

a. Mengambil keputusan

b. Mengadakan komunikasi agar saling pengertian antara manajer dan bawahan.

c. Memberi semangat, inspirasi dan dorongan kepada bawahan supaya mereka bisa bertindak.

d. Memilih orang-orang yang menjadi anggota kelompoknya.

e. Memperbaiki pengetahuan dan sikap-sikap bawahan agar mereka terampil dalam usaha mencapai tujuan yang ditetapkan.

4. Directing/commading adalah fungsi manajemen yang berhubungan dengan usaha memberi bimbingan, saran, perintah-perintah atau intruksi kepada bawahan dalam melaksanakan tugas masing-masing, agar tugas dapat dilaksanakan dengan baik dan benar-benar tertuju pada tujuan yang telah ditetapkan.

\section{Kepemimpinan}

Kepemimpinan merupakan sebuah fenomena universal. Siapa pun menjalankan tugas-tugas kepemimpinan, manakala dalam tugas itu dia berinteraksi dengan orang lain. Bahkan dalam kapasitas pribadi pun, di dalam tubuh manusia itu ada kapasitas atau potensi pengendali, yang pada intinya memfasilitasi seseorang untuk dapat memimpin dirinya sendiri.

Menurut D.E. Mc. Farland mengemukakan bahwa kepemimpinan adalah suatu proses dimana pimpinan dilukiskan akan memberi perintah atau pengaruh, bimbingan atau proses mempengaruhi pekerjaan orang lain dalam memilih dan mencapai tujuan yang telah ditetapkan.

Sedangkan menurut Dr. Sudarwan Danim mendefinisikan kepemimpinan adalah setiap tindakan yang dilakukan oleh individu atau kelompok untuk mengkoordinasi dan memberi arah kepada individu atau kelompok lain yang tergabung dalam wadah tertentu untuk mencapai tujuan-tujuan yang telah ditetapkan sebelumnya. 
Dari beberapa pengertian kepemimpinan di atas, pada dasarnya kepemimpinan mirip dengan manajemen, kepemimpinan merupakan hubungan dimana seorang pemimpin memengaruhi pihak untuk bekerja sama secara sukarela dalam usaha mengerjakan tugas-tugas yang berhubungan untuk mencapai hal yang diinginkan oleh pemimpin tersebut.

Pemimpin dan kepemimpinan adalah ibarat sekeping mata uang logam yang tidak dapat dipisahkan, dalam artian bisa dikaji secara terpisah namun harus dilihat sebagai satu kesatuan. Seorang pemimpin harus memiliki jiwa kepemimpinan dan jiwa kepemimpinan yang di miliki dari seseorang pemimpin adalah tidak bisa diperoleh dengan cepat dan segera, namun sebuah proses yang terbentuk dari waktu ke waktu hingga akhirnya mengkristal dalam sebuah karakteristik (Irham Fahmi, 2018).

Kepemimpinan adalah membina, menggerakkan, mengarahkan, dan memerintah anggota melakukan tindakan (aksi) untuk mencapai tujuan. Tugas pemimpin adalah (Abdul Rivai dan Darsono Prawironegoro, 2015):

a. Mengorganisasi diri sendiri

b. Mengorganisasi anggota untuk melakukan tindakan (aksi)

Untuk melaksanakan tugas itu pimpinan harus melakuakan aktivitas antara lain (Abdul Rivai dan Darsono Prawironegoro, 2015):

a. Adaptasi budaya dan partisipasi aktif dengan anggota

b. Mendidik anggota agar mereka mengetahui dan memahami kondisi objektif ekonomi, sosial, politik dan budaya.

c. Meneguhkan pendirian anggota agar mereka sadar akan dirinya dan kepentingannya, dan sadar akan kelompoknya atau kelasnya.

d. Membangkitkan semangat anggota agar berani bertindak untuk mencapai kepentingannya.

e. Mengorganisasi dan memimpin anggota untuk melakukan tindakan untuk mencapai kepentingannya.

\section{Prinsip Kepemimpinana Islami}

\section{Musyawarah}

Seorang pemimpin selain harus menerima dan mendapatkan tausiyah atau kritikan, juga selalu bermusyawarah. Al-Quran dengan jelas menyatakan bahwa seorang yang menyebut dirinya sebagai pemimpin wajib melakukan musyawarah dengan orang 
yang berpengetahuan atau orang yang berpandangan baik. Sebagaimana firman Allah SWT dalam surah Asy-Syura ayat 38:

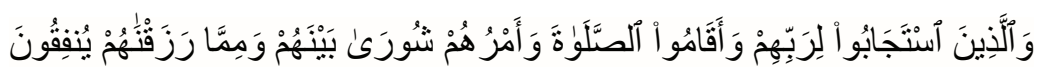

Artinya: Dan (bagi) orang-orang yang menerima (mematuhi) seruan Tuhannya dan mendirikan salat, sedang urusan mereka (diputuskan) dengan musyawarah antara mereka; dan mereka menafkahkan sebagian dari rezeki yang kami berikan kepada mereka.

Musyawarah ini ditujukan untuk saling bertukar pendapat dan pemikiran. Jika musyawarah berjalan dengan baik, para karyawan akan merasa termotivasi karena mereka merasa dilibatkan dalam pengambilan keputusan, yang berkaitan dengan perusahaan dan kehidupan mereka. Dengan musyawarah ada unsur penghargaan yang tersirat dari seorang pemimpin untuk menerima masukan-masukan dari para karyawan. Hal ini berdampak positif mengingat bahwa karyawan adalah manusia yang harus “dimanusiakan", bukan sekedar robot yang dengan seenaknya dapat diperintahkan apa saja (Nana Herdiana Abdurrahman, 2013).

\section{Kejujuran}

Pemimpin yang baik itu harus memiliki kejujuran yang tinggi yaitu jujur pada diri sendiri dan pada orang lain (terutama bawahannya). Dia selalu menepati janji, tidak munafik, dapat dipercaya, dan berlaku adil terhadap semua orang.

Jujur merupakan modal dasar seorang pebisnis yang beretika dan berakhlak. Rasulullah Saw pernah bersabda, "Tetapkanlah kejujuran karena sesungguhnya kejujuran mengantarkan kepada kebaikan dan sesungguhnya kebaikan mengantarkan kepada surga." Sifat jujur harus dibangun kepada semua pihak pelaku bisnis, baik pemerintah, pelanggan, pemegang saham maupun pemimpin kepada karyawan lainnya.

\section{Keterbukaan}

Mau menerima saran dan kritik, transparan dalam merencanakan dan melaksanakan tugas. Langkah terbaik mengatasi rasa takut adalah memanfaatkannya sebagai pegangan sifat hati.hati. Ada perbedaan antara tidak mau didekte oleh rasa takut, tidak percaya diri, dengan berani terbuka. Ketika kita sudah di posisi bos atau orang yang diprioritaskan di perusahaan, sudah sepantasnya kita memiliki sifat terbuka dalam hal operasioal yang sifatnya materiil ataupun non materiil (Ahmad Jarifin, 2019). 
Pemimpin itu harus bersifat terbuka; merasa utuh bersatu, sejiwa dan seperasaan dengan anak buahnya bahkan merasa senasib dan sepenanggungan dalam satu perjuangan yang sama. Karena itu dia bersedia memberikan pelayanan dan pengorbanan kepada para pengikutnya. Sedang kelompok yang dituntun menjadi semakin percaya dan semakin menghormati pemimpinnya.

\section{Keadilan}

Pengertian "adil" dalam bahasa Indonesia sebenarnya bersumber dari ajaran Islam, yaitu kata Arab 'adl. Pemerintah atau pemimpin selalu berhadapan dengan masyarakat yang terdiri dari kelompok-kelompok. Seorang yang terpilih menjadi pemimpin harus mampu berdiri di atas semua golongan. Untuk itu diperlukan sifat keadilan.

Bertindak secara adil berarti mengetahui hak dan kewajiban, mengerti mana yang benar dan yang salah, bertindak jujur dan tepat menurut peraturan dan hukum yang telah ditetapkan serta tidak bertindak sewenang-wenang. Keadilan ini penting bagi seorang pemimpin dalam menjalankan organisasi yang dipimpinnya. Mendorong pemimpin dalam situasi apapun tidak boleh memihak pada suatu kelompok atau golongan tertentu dalam sistem organisasi.

Dalam al-Qur'an terdapat perintah amanah yang berlaku adil. Ayat ini berkaitan dengan pemegang pemerintahan. Sebagaimana firman Allah dalam Q.S An-Nisaa' ayat 58:

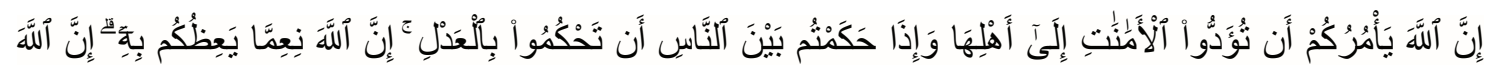

$$
\begin{aligned}
& \text { كَانَ سَمِيعًا بَصِيرًا }
\end{aligned}
$$

Artinya: Sesungguhnya Allah menyuruh kamu menyampaikan amanat kepada yang berhak menerimanya, dan (menyuruh kamu) apabila menetapkan hukum di antara manusia supaya kamu menetapkan dengan adil. Sesungguhnya Allah memberi pengajaran yang sebaik-baiknya kepadamu. Sesungguhnya Allah adalah Maha Mendengar lagi Maha Melihat.

\section{Amanah}

Dalam Kamus Kontemporer (al-Ashr) Amanah diartikan dengan kejujuran, kepercayaan (hal dapat dipercaya). Amanah ini merupakan salah satu sifat wajib bagi Rasul. Ada sebuah ungkapan "kekuasan adalah amanah, karena itu harus dilaksanakan 
dengan penuh amanah”. Ungkapan ini menurut Said Agil Husin Al-Munawwar, menyiratkan dua hal.

Pertama, apabila manusia menjadi khalifah di bumi sesungguhnya kekuasaan yang diperolehnya sebagai suatu pendelegasian kewenangan dari Allah Swt. Sebab Allah sebagai sumber segala kekuasaan. Kekuaasaan yang dimiliki manusia adalah sebuah amanah yang harus dipertanggung jawabkan kepada-Nya.

Kedua, karena kekuasaan itu pada dasarnya amanah, maka pelaksanaannyapun memerlukan amanah. Amanah dalam hal ini adalah sikap penuh tanggung jawab, jujur dan memegang teguh prinsip.

\section{METODE PENELITIAN}

Metode penelitian pada dasarnya merupakan cara ilmiah untuk mendapatkan data dengan tujuan dan kegunaan tertentu (Sugiono, 2018). Dalam melaksanakan sebuah penelitian, metode merupakan salah satu hal penting. Dengan menggunakan suatu metode maka penelitian yang dilakukan akan lebih mudah dilakukan oleh seorang peneliti. Penelitian yang dilakukan akan mendapatkan hasil penelitian dengan mudah dan cepat.

Dalam penelitian ini peneliti menggunakan pendekatan Penelitian lapangan (Field Research) dapat juga dianggap sebagai pendekatan luas dalam penelitian kualitatif atau sebagai metode untuk mengumpulkan data kualitatif (Lexy J. Moleong, 2012). Metode penelitian kualitatif ini sering disebut penelitian naturalistik karena penelitiannya dilakukan pada kondisi yang alamiah (natural setting) (Asifuddin dan Beni A Saebani, 2012).

Penelitian ini merupakan penelitian yang bersifat lapangan dan menggunakan metode penelitian kuatitif yang mengharuskan untuk terjun ke lokasi penelitan untuk mendapatkan data yang konkrit dan tepat. Selain itu juga peneliti merupakan instrument penting dalam penelitian ini dalam mengumpulkan data di lapangan. Dalam hal ini peneliti harus memberikan kesan baik dan menciptakan suasana berkomunikasi yang nyaman guna mendapatkan data primer maupun skunder yang diingikan.

Secara umum, sumber data yang diperoleh oleh peneliti dalam penelitian ini terdiri dari dua macam, yaitu: 
a. Sumber data Primer adalah sumber data yang langsung memberikan data kepada pengumpul data. Sehingga dengan demikian yang menjadi sumber data primer disini adalah wawancara langsung kepada pimpinan UD Iqbal Jaya Bondowoso.

b. Sumber data Sekunder adalah sumber data tidak secara langsung memberikan data pada pengumpul data. Sehingga data sekunder ini dapat berupa buku, artikel, jurnal, majalah atau data dari internet yang berkaitan dengan penelitian yang dilakukan.

Untuk menghasilkan data yang sempurna maka peneliti menggunakan teknik pengumpulan data. Teknik pengumpulan data merupakan langkah yang paling strategis dalam penelitian, karena tujuan utama dari penelitian adalah mendapatkan data (Sugiono, 2018). Dalam masalah penelitian ini, peneliti melakukan pengumpulan data dengan beberapa metode, diantaranya:

a. Observasi

Observasi adalah pengamatan dan pencatatan secara sitematis terhadap fenomena-fenomena yang diteliti. Memang konsep observasi berasal dari bahasa latin yang berarti melihat dan memperlihatkan, kemudian observasi diarahkan pada kegiatan memperhatikan secara akurat, mencatat fenomena yang muncul, terutama dalam disiplin ilmu, baik ilmu eksakta maupun ilmu-ilmu sosial. Dengan demikian peneliti harus berpedoman kepada desain penelitian.

b. Dokumentasi

Dokumentasi adalah teknik mencari data mengenai segala yang berupa catatan, transkip, buku, surat kabar, majalah, agenda dan lainnya. Metode ini memiliki tingkat kebenaran yang lebih tinggi, karena kejadian suatu proses dapat terungkap secara imperis dan selanjutnya dapat dijadikan sebagai bukti yang sangat kuat.

c. Wawancara

Wawancara adalah tehnik pengumpulan data melalui pengamatan dengan melakukan tanya jawab secara lisan. Metode ini digunakan dengan cara wawancara terbuka untuk memperoleh data yang akurat dan optimal. Data yang dilaporkan harusalah deskriptif dan menyajikan pemaknaan data tersebut. Kegiatan ini dilakukan kepada pihak-pihak terkait untuk mendapat data yang dibutuhkan (Nawawi, 2014). 
Setelah data yang diperlukan oleh peneliti terkumpul, maka peneliti akan mengelola data yang didapat dalam suatu metode tertentu agar data tersebut lebih proporsional dan representatif. Dalam penelitian kualitatif, data diperoleh dari berbagai sumber, dengan menggunakan teknik pengumpulan data yang bermacam-macam (triangulasi), dan dilakukan secara terus-menerus sampai datanya jenuh.

\section{HASIL DAN PEMBAHASAN}

\section{Manajemen Kepemimpinan Islami Dalam Meningkatkan Kinerja Karyawan di UD Iqbal Jaya Bondowoso}

Pada praktiknya, manajemen yang digunakan di UD Iqbal Jaya Bondowoso adalah manajemen kepemimpian dengan dilandaskan sistem kekeluargaan dengan tidak membuang sikap hormat antara bawahan ke atasan. Dengan kata lain manajemen yang di terapkan di UD Iqbal Jaya adalah model manajemen kepemimpinan partisipatif dalam artian manajemen kepemimpinan yang memberikan kesempatan kepada bawahannya untuk secara aktif baik mental, spiritual, fisik, maupun material dalam kiprah di organisasi. Sebagaimana yang telah di aplikasikan di lapangan bahwa UD tersebut menerapkan bagaimana tidak hanya atasannya yang aktif namun juga bawahannya.

Kepemimpinan yang ingin diwujudkan oleh UD Iqbal Jaya adalah kepemimpinan yang mengedepankan nilai-nilai moral dan ibadah dalam segala aktivitas. Sebagai langkah awal dalam kepemimipinan pak Hamadin senantiasa berusaha untuk meneladani sifat pemimpin yang telah di ajarkan oleh nabi Muhammad SAW. Hal ini dilakukan oleh pak Hamadin agar dalam memimpin UD iqbal Jaya pak Hamadin menjadi sosok yang disenangi sehingga akan mudah untuk memenej pekerjaan para karyawannya. Oleh karena itu bapak Hamadin berusaha untuk mengikuti 4 sifat yang telah diajarkan oleh nabi Muhammad S.A.W.

a. Sidiq atau jujur, selaku pemilik atau pimpinan bapak Hamadin senantiasa menanamkan sifat kejujuran pada setiap karyawannya. Hal ini terbukti dengan kejujuran bapak hamadin dalam pembagian tugas dan gaji karyawan. Gaji karyawan diberikan oleh pak hamadin sesuai dengan apa yang telah dikerjakan oleh karyawannya.

b. Amanah atau dapat dipercaya dalam hal ini bapak Hamadin memiliki rasa tanggung jawab yang tinggi dan melaksanakan tugas dengan baik terutama dalam hal menjaga 
kebersamaan di UD Iqbal Jaya. Bagi pak Hamadin UD Iqbal Jaya adalah Amanah dari Allah yang dititpkan kepadanya, oleh karena itu pak Hamadin tidak berlaku semena-mena terhadap karyawannya. dari sikap ini lahirlah para karyawan yang memiliki himmah yang sangat tinggi terhadap amanah pekerjaan meeka.

c. Fathonah atau cerdas dalam hal ini UD Iqbal Jaya selalu memiliki inovasi atau model bekerja, sehingga para karyawan merasa aman dan nyaman dengan apa yang telah mereka lakukan dengan sifat fatonah ini UD iqbal Jaya mampu memecahkan masalah, memiliki konsep serta memperluas pengetahuan.

d. Tabligh atau menyampaikan bagi bapak hamadin apa yang telah diperoleh oleh karyawannya tau apa yang menjadi hak bagi karyawannya harus tersampaikan dengan baik tanpa ada pengurangan sedikit pun.

Bagi UD iqbal Jaya persatuan dan kesatuan merupakan hal yang utama yang harus dibangun, oleh karena itu ada beberapa langkah yang diterapkan oleh UD Iqbal Jaya dalam mengambil keputusan terkait dengan kebutuhan UD.

\section{Musyawarah}

Seorang pemimpin selain harus menerima kritikan atau pun sara dari bawahannnya, begitupun dengan pimpinan UD Iqbal Jaya. dalam hal ini bapak Hamadin senantiasa mengajak para karyawannya dalam membuat kebijakan di UD. Bagi pak hamadin sekalipun beliau adalah pemimpin namun musyawarah adalah hal utama, juga selalu bermusyawarah. Dalam hal ini aspek keputusan bersama menjadi kunci utama UD Iqbal Jaya.

\section{Keterbukaan}

Dalam hal memimpin bapak Hamadin selalu menerapkan rasa keterbukaan merasa utuh bersatu, sejiwa dan seperasaan dengan anak buahnya bahkan merasa senasib dan sepenanggungan dalam satu perjuangan yang sama. Karena itu dia bersedia memberikan pelayanan dan pengorbanan kepada para pengikutnya. Sedang kelompok yang dituntun menjadi semakin percaya dan semakin menghormati pemimpinnya.

\section{KESIMPULAN}

UD Iqbal Jaya Adalah UD yang bergerak di bidang produksi tahu yang telah berdiri sekitar kurang lebih 20 tahun. Kepemimpinana pada UD Iqbal Jaya menggunakan pendekatan Manajemen kepemimpinan Islami. Dalam aktifitasnya UD 
Iqbal Jaya senantiasa berusaha menerapkan sifat kepemimpina nabi Muhammad S.A.W. karena dengan menerapkan sifat-sifat tersebut akan meningkatkan kinerja karyawan.

\section{DAFTAR PUSTAKA}

Abdul Rivai dan Darsono Prawironegoro. (2015). Manajemen Strategis. Jakarta: Mitra Wacana Media.

Ahmad Jarifin. (2019). Strategi Bisnis Ala Rasulullah yang Tak Pernah Rugi. Yogyakarta: Araska.

Anang Firmansyah. (2019). Manajemen. Qiara Media.

Asifuddin dan Beni A Saebani. (2012). Metodologi Penelitian Kualitatif. Bandung: CV Pustaka Setia.

Hadari Nawawi. (1993). Kepemimpinan Menurut Islam. Yogyakarta: Gadjah Mada University Press.

Hendri Safri. (2017). Manajemen dan Organisasi dalm Pandangan Islam. Jurnal Of Education Management, 156.

Hendyat Soetopo. (1992). Pengantar Operasional Administrasi. Surabaya: Usaha Nasional.

Irham Fahmi. (2018). Pengantar Ilmu Kepemimpinan. Depok: PT. Rajagrafindo Persada.

John Supriyanto. (2014). Manajemen. Yogyakarta: Gadjah Mada University Press.

Lexy J. Moleong. (2012). Metode Penelitian Kualitatif. Bandung: PT Remaja Rosdakarya Offset.

Muhammad. (2012). Manajemen Bank Syari'ah. Yogyakarta: STIM TKPN.

Muhammad Nizar. (2018). Prinsip Prinsip Manajemen Syari'ah. Jurnal Istiqro' , 115.

Muhammad Syafi'i Antonio. (2007). Muhammad SAW The Super Leader Super Manager. Jakarta: Tazkia Multimedia.

Nana Herdiana Abdurrahman. (2013). Manajemen Bisnis Syari'ah \& Kewirausahaan. Bandung: CV Pustaka Setia.

Nawawi. (2014). Metodologi Penelitian Hukum Islam. Malang: Genius Media.

Onong Uchjana Efendi. (2009). Human Relation \& Public Relation. Bandung : CV Mandar Maju.

Sugiono. (2018). Metode Penelitian Kuantitatif dan R\&D. Bandung: Alfabeta. 